\title{
Russian Language as a Factor of Strengthening Unified Humanitarian and Educational Space of CIS: Russia-Armenia
}

\author{
Tigran E. Marinosyan ${ }^{1, *}$, and Yulia G. Kurovskaya ${ }^{2}$ \\ ${ }_{2}^{1}$ ISED RAE, Laboratory of Theoretical Pedagogy and Philosophy of Education, 105062, Moscow, Russia \\ 2 ISED RAE, Academic Secretary, 105062, Moscow, Russia
}

\begin{abstract}
The article deals with the problem of language unity and communication gaps between the post-Soviet countries retrospectively, which is important for determining the direction of the future development of the members of the Commonwealth of Independent States (CIS). The focus is on the language situation in Russia and Armenia, two countries which have longstanding and strong friendly bonds based on successful cooperation in addressing important international problems, including in the education sphere. The aspects covered in the article include normative-legal documentation regulating state language policies; the role of the native language in education; the issue of the status of the Russian language in oral and written communication.
\end{abstract}

The relations between the peoples inhabiting Russia have played an important and in many ways critical role in the history of the formation and development of the Russian multinational state. The study of the relationships among the peoples living on Russia's territory has been relevant at all times not only for politicians and various representatives of the scientific community. Active cooperation with the countries of the "near" and "far" abroad is a key element of Russia's innovative projects and programs. Today, as in the past, CIS countries are arenas of clashing interests of various states and peoples. The interest of scholars - historians, philosophers, sociologists, cultural specialists and ethnographers - in the study of the relations between Russia and the Commonwealth countries is unflagging. Education is one of the areas in which Russia and the Commonwealth countries traditionally have a mutual interest.

Solution of current educational tasks facing the CIS countries in the process of forming a unified educational space calls for new approaches because the integration of pedagogical communities in the Commonwealth states cannot proceed on the same basis and in the same forms as in the Soviet times. The formation of a unified educational space of the CIS throws up not only various organizational, but also strictly pedagogical problems whose solution will be instrumental in revealing the organizational-pedagogical conditions for effective implementation of interstate agreements and programs in the education field while taking into account the national interests of the Commonwealth member countries. In the process of self-determination of CIS countries it is becoming important to identify the main areas and effective ways of deepening these relations and interactions. Of particular importance is the problem of preserving, strengthening and expanding the common language basis on the Commonwealth territory, the use of Russian as the universal instrument of forming a unified educational space and the development of relations among CIS countries in general.

The twenty-year period between 1991 and 2011 was a complicated period for the post-Soviet countries which saw changes in the awareness of national and civic identity of the populations in these states, attempts to acquire a new identity as a nation and citizens of a separate state which was once part of a single country. This is very important because "certainty about the position of national identity brings certainty to selfawareness of all the citizens and makes an imprint on their perception of the world, behavior, mores, morality and spirit. Ultimately this determines the country's future, the outcome of events resulting from the answers to the challenges of the contemporary unstable world," [1, p.7].

On the whole the 20-year stretch in Russia's development can be divided into two stages which are characterized in the work of Svetlana V. Ivanova:

"The 1990s, the period of "change," "wrecking" of the state system, the political regime with destructive consequences for the economy and the social sphere.

The 2000s saw state and political reforms combined with a quest for stability, reform and modernization of all the sectors of the economy and the social sphere, including education" [2, p.176].

Such roller-coaster historical development undoubtedly had a major impact on the process of modernization of the content of general education [for more detail see: 3 ] and the role of the Russian language

\footnotetext{
Corresponding author: moscowline@mail.ru
} 
in the educational policies of post-Soviet countries. Bearing in mind the special status of the Russian language as a unifying factor in the CIS, let us consider aspects that offer an insight into the problem of language unity and communication gaps in the post-Soviet space retrospectively, which is important for determining the direction of future development of Commonwealth countries because "the past (that which has already happened) is built into the present and remains relevant for the future by providing pointers to what a person is, what may happen in his/her life and the life of society" [4, pp.6-7].

The issue of language policy and the Russian language is examined in this article with reference to two countries: Russia and Armenia, countries which have strong friendly relations based on long-standing traditions of cooperation on the majority of key international problems, including the aspects of strengthening the CIS. Expert opinions were provided by representatives of education authorities, research scholars and Russian and Armenian specialists in the fields of pedagogy and education.

Let us first take a look at the legal framework in the said area. According to the Director of the Education Development Strategy Institute of the Russian Academy of Education, Professor Svetlana V.Ivanova, Dr.Sc. (Philosophy) the position of the state (ie. Russian) language in Russia is sealed in its legislation. First and foremost, this is reflected in the Constitution of the Russian Federation which proclaims Russian to be the official language of the Russian Federation throughout its territory.

The Federal Law of the Russian Federation of June 1, $2005 N$ 53-FZ On the State Language of the Russian Federation [5] which came into effect on June 7, 2005 is aimed at ensuring the use of the state language of the Russian Federation throughout the territory of the Russian Federation, at securing the right of the citizens of the Russian Federation to use the state language of the Russian Federation and at protecting and developing the language culture.

The status of the Russian language as the state language is confirmed by other regulatory acts, for example, the Law of the Russian Federation of October 25, 1991 №1807-I On the Languages of the Peoples of the Russian Federation [6]. This, the first law of new Russia concerning the state language policy, recognizes the languages of the peoples of the Russian Federation to be the national heritage of the Russian state that is protected by the state. The state throughout the territory of the Russian Federation promotes the development of national languages, bilingualism and multilingualism. The Russian Federation does not tolerate the propaganda of hostility and neglect toward any language, the creation of obstacles, restrictions and privileges in the use of languages contrary to the constitutional principles of nationalities policy and other violations of the legislation of the Russian Federation on the languages of the peoples of the Russian Federation. It took almost 15 years for the law on state language to be passed as it was thoroughly prepared as part of the Duma (Lower House of the Federal Assembly of the Russian
Federation) activities and in implementing the Russian Language Federal Targeted Program. Among other serious tasks, this program contributed to localization and to diminishing the centrifugal trends in the language policies of the Russian regions which seek to exercise their sovereignty to the full, including by developing their own languages in the national republics at the expense of the Russian language. Such trends have been observed in a number of national republics. With "sovereignties vying with one another" preparing and passing the law on the state language was an uphill struggle. The Law on State Language gave a boost to the Russian language, the development of the Russianspeaking space in Russia and strengthened its position in the regions. Today it is hard to imagine that there was a real danger of teaching in Russian being banned in schools. Some regions, seeking to shore up their national language (good idea, if not carried to extremes) wanted the teaching at the basic and senior school levels to be switched to the local language. Incidentally, in the Soviet Union teaching was conducted in more than 130 national languages with the preservation of the Russian language.

In Armenia, according to the expert opinion of Lilia G.Balasanyan, Ph.D. (Pedagogy), Chief Specialist of the Department of Schools of the Ministry of Education and Science of the Republic of Armenia and President of the Armenian Association of Teachers of the Russian Language and Literature at General Education Schools, the language situation is as follows. In 1991 it was regulated by the Law of the USSR of April 2004, 1990 On the Languages of the Peoples of the USSR [7], which established Russian as the official language of the USSR. In practice, of course, Russian was the language of international communication while the other languages were far from its equals in terms of their real rights and functions. At the time Armenian education was part of the standard Soviet model of total state control of study programs and methods of teaching and close integration of educational activities with other aspects of society, such as politics, culture and economics. Like in the Soviet times, primary and secondary education in Armenia is free and secondary education is compulsory.

The 2011 Constitution of the Republic of Armenia [8], under Article 12, establishes Armenian as the official language, and under Article 37 guarantees the right of representatives of ethnic minorities to preserve their traditions and develop their languages and culture. The status of the Russian language is not defined.

The main provisions of the language policy of the Republic of Armenia are also set forth in the following documents:

1. The Law of the Republic of Armenia On Language (adopted on April 17, 1993) [9] regulates the status of language, language relations among state power and administration organs, enterprises, institutions and organizations.

2. The European Charter for Regional or Minority Languages (the Republic of Armenia ratified the European Charter for Regional Languages on January 22, 2002) recognizing Yezidic, Russian, Greek and Assyrian as minority languages. 
3. The State Program of Language Policy in the Republic of Armenia whose main provisions establish that the primacy of the state language of the Republic of Armenia is harmoniously combined with the preservation of the languages of national minorities in accordance with the provisions of international law and language policy of the Council of Europe on the basis of the principle of mutual respect of all cultures. The Program was to be implemented in the period between 2002 and 2005. The program of the RA in the sphere of minority languages envisages actions aimed at rendering every kind of support to the preservation and development of minority languages; support of productive linguistic communication and mutual understanding between national minorities in accordance with the language policy of the Council of Europe; committing the scientific and teaching resources of a given nationality to ensure the right of national minorities to education and upbringing in their native language; assisting the retraining and training of the teachers of minority languages.

In considering state priorities in the teaching of foreign languages in Russia expert Svetlana V.Ivanova notes that the situation with foreign language teaching reveals common trends at various stages of education, for example, diversity of textbooks, a lack of the ideological component in the textbooks that was characteristic of the Soviet period, modern methods oriented toward spoken and business oral speech (through language practice) more than toward mastering written speech and grammar. However, every situation should be considered on its merits in detail by specialists who professionally develop standards, educational programs and foreign language textbooks. Funding is allocated in accordance with the standard and the curriculum. Usually the state supports the teaching of one foreign language. However, gymnasiums and specialized schools may teach two or more languages.

Non-state schools offer a fairly wide choice of languages for study. More often than not preference is given to the study of English, the second foreign language being French, German or Spanish in the European part of Russia, while in the Russian Far East and Siberia the Chinese language is popular. Russian schools and higher education institutions increasingly seek to offer their students an opportunity to study several foreign languages: English, German, and French. If a school can afford to teach a third language, it tends to be Italian, Spanish, Chinese, Japanese and Arabic.

In Armenia, according to expert Lilia G.Balasanyan, priority in foreign language teaching at state schools is given (in descending order) to: Russian, English, French and German. In 2011 these were Russian, English, French, German, Spanish, Italian and Persian languages.

Since 1999 the republic has been implementing the Concept Russian Language in the Education System and Socio-Cultural Life of the Republic of Armenia adopted by the RA Government. At present, in accordance with the regulations on schools that offer higher standards of Russian language teaching approved in 2000, Armenia has more than 60 schools, with 40 schools teaching in Russian. At all the general education schools in the RA
Russian is an obligatory language since year 2, taught as a separate discipline or as a foreign language while other foreign languages are taught only beginning from year 5 .

Russian occupies a special place in the Armenian secondary education system in-between native Armenian and foreign languages (mainly English, much less French, German, Spanish and Persian). In accordance with the curricula, foreign languages are taught for 1-2 hours a week starting from year 2. Russian, however, is studied by Armenian school pupils 2-3 hours a week from year 1 . Both the Armenian authorities and society at large consider the study of Russian to be a priority.

The Republic also has schools with special classes where all the teaching is conducted in Russian according to Russian textbooks and programs. School-leavers pass a standard centralized examination in Russian language and literature. Republican Olympiads in the Russian language are held for school students every year.

Russian is taught at education institutions according to state standards that determine the required level of proficiency that enables school leavers to continue studying in Russian at higher education institutions in Armenia and Russia.

The number of foreign books translated into Armenian every year is insignificant -- a little over ten which means that anyone who wants to gain access to the wealth of world civilization through the printed word has to study Russian or some other foreign language (the latter is far more difficult because while people hear Russian all around them, this is not the case with English, let alone German, French and other languages).

In 2012 the Russian language was given the status equal to that of other foreign languages. Command of Russian by school and university students today has deteriorated markedly compared to the Soviet period [10].

At present the Republic has four state higher education institutions that train teachers of the Russian language and literature. The departments at these education institutions offer post-graduate, higher doctorate programs and training for degree candidates. Regular seminars and conferences are held for Russian language and literature teachers to which top philologists and linguists from Russia are invited.

Since 2009 Armenia has had the Association of Russian Language Teachers at Armenian Schools whose aim is to provide conditions for professional growth of Russian language and literature teachers in the Republic. The Association's aims are to improve the system of exchange of experience among Russian language teachers, contribute to the implementation of innovative technologies of pedagogic activities of Russian language and literature teachers, organize methodological and practical assistance to Russian language teachers in preparing students for Olympiads on Russian territory and for study at Russian higher education institutions.

The Russian Study and Methodological Center of the Russian Language under the auspices of Rossotrudnichestvo (The Federal Agency for the Commonwealth of Independent States, Compatriots Living Abroad, and International Humanitarian Cooperation) office in Armenia aims to popularize the 
Russian language in Armenia, expand and strengthen the educational space of the Russian language and culture, create the necessary conditions for practical use of Russian, education in Russian, assist in the study and spread the Russian language as an inseparable part of world culture and a potent instrument of developing integration processes and international communication and the working language of the Commonwealth of Independent States.

The Association runs Russian-language courses for:

- children of various age who seek to deepen their knowledge of Russian and expand the sphere of its use;

- employees of state institutions and military and security structures, various industrial enterprises and the services sphere (short-term and intensive courses);

- graduates of Russian and Soviet higher education institutions who seek to maintain their standard of Russian and their links with Russia;

- young people wishing to acquire a higher education in Russia.

The office of Rossotrudnichestvo in the RA also has a consultancy center for those who seek to study at Russian higher education institutions.

Distance learning of Russian is successfully used in the Republic. Its users include Russian servicemen and members of their families, Russian nationals living in Armenia and a certain contingent of Armenian citizens who have chosen education in Russian. Taking part in the development and dissemination of new information technologies used in distance learning are local education institutions jointly with the local branches of Russian higher education institutions.

Armenia holds annual conferences, seminars on the theory and methodology of teaching Russian, publishes the journal Russian Language in Armenia (in Russian) for teachers, one of whose co-funders is the Educational Reform Center of the Ministry of Education and Science of the Republic of Armenia.

Next it is important to consider the position of the native language in oral and written communication. In Russia the position of the native language in oral communication varies from one constituent republic to another, as pointed out by Svetlana V. Ivanova. In the scientific field the main vehicle of communication is Russian. Business communication, given the modern level of integration of business, is most conveniently conducted in Russian, which is the international lingua franca. The native language is often used in daily life, especially in areas that are remote from industrial and cultural centers.

In the sphere of written communication events may develop in one of three ways:

- support of the Russian language, its teaching, the existence of Russian-language schools (for example, in Kazakhstan, Belarus, Armenia and Kyrgyzstan);

- resistance to the Russian language, refusal to teach it even in areas with Russian-speaking population (for example, Ukraine and the Baltic countries);

- indifferent attitude to language problems (no opposition, no support), as in Azerbaijan and Turkmenistan. In general, the issue is very complicated and calls for separate in-depth study.
According to the expert opinion of Lilia G.Balasanyan, in 1991 Armenia had de jure two native languages, Armenian and Russian. Russian is seen as the all-union main language of international communication and of course of official paperwork. It is still the second native tongue, however at present practically all the schools are switching to Armenian. The same is happening to Russian departments at higher education institutions, which in practice deprives Russian of its status as the second native tongue and relegates it to the category of optional foreign languages. This changes the form of its functioning and reduces the total number of people who study the language in traditional forms.

The language situation has been turning around since 1996 as the study of Russian became relevant again. Since 1999 the journal The Russian Language in Armenia has been published, scientific and scientificmethodological conferences have been held devoted to typology and comparison of languages, modern problems of the theory and methods of teaching Russian, etc. The Russian-Armenian (Slavonic) State University (RAU) founded in Yerevan in 1997 contributes to the training of specialists who meet modern requirements and have good command both of the native and Russian languages [11, pp. 20-21].

Since 2011 only one language - Armenian - has been the official language. Russian in Armenia performs various functions as a native language, second language, main foreign language, and as lingua franca. The diversity of functions is reflected in the diversity of types of schools depending on how the Russian language is taught:

- 47 schools with special classes where all teaching is in Russian;

- 26 schools with bilingual and in-depth study of the Russian language;

- two totally Russian schools;

- five schools of the Russian Federation for the children of Russian citizens without the teaching of Armenian [12].

At present the educational system in the country is governed by the Law of the Republic of Armenia on Education passed by the National Assembly of the RA in 1999, the State Program of the Development of Education in Armenia for 2011-2015, and state education standards approved by the RA Government.

According to the 2001 population census, $85 \%$ of the population of Armenia have a command of Russian, $13 \%$ consider Russian to be their native tongue, which is 30 times more than the size of the Russian community. Russian has been named as the native language by members of other minorities (Greeks, some members of the Assyrian community, Jews and Belarussians). The majority of native Russian speakers are Armenians who have come from Russia or other regions of the former USSR; Armenians who have been educated in Russian inside Armenia; as well as refugees (in $1988-1994$ Armenia received more than 350,000 refugees mainly from Azerbaijan as well as Abkhazia, the North Caucasus and Nagornyi Karabakh, most of whom are native Russian speakers). However, it is obvious that intensive functioning of the Russian language in its main 
spheres - the media, science and culture - is ensured not only by the $13 \%$ who consider Russian to be their native language, but also by the majority (85\%) who know enough Russian for passive communication [12].

Between 1990 and 2011 the number of schools with teaching in Russian and the number of those studying in Russian in Armenia has been plummeting.

In a Gallup poll conducted in 2008, $94 \%$ of respondents when asked whether teaching of the Russian language in Armenia was important, replied in the affirmative. This despite the fact that there are only 15,000 ethnic Russians living in the country today. [13].

According to Armenian Russian language specialists, up to $70 \%$ of the Republic's population (about 2.5 million people) can communicate in Russian, while about $35 \%$ of people over 40 are fluent in Russian [14, p.27].

“The position of the Russian language in the county's cultural and information sphere remains secure. ORT and RTR channels are relayed in the one-meter band all over the Republic; in addition NTV, TVC Moskva, MusTV are beamed to Yerevan. Present on the air are the radio stations Mayak and GolosRossii (The Voice of Russia) and Russkoye Radio (Russian Radio) is very active. The Russian-language press is represented in Armenia by a whole range of papers the most popular and widely circulated being the social-political periodicals Respublika Armenia, GolosArmenii and Novoyevremya(New Times). Russian periodicals are poorly represented in Armenia" [14, p.28].

To sum up, the Russian language and nationalRussian bilingualism in Armenia are fairly wide-spread. The Russian language in Armenia is still a powerful integrating factor, a vehicle of ideas, concepts, identity, myths and the narrative of the post-Soviet civilization, which is important for effective and balanced interaction of the Commonwealth countries in the field of education and hence for the future of every country because "What is good for the country is good for the people and the country's future, it means future opportunities for its children, all of which is the responsibility of the education system" $[15, \mathrm{p} .13]$.

This work was financed by Grant No. 14-06-00650 of the Russian Humanitarian Scientific Fund.

\section{References}

1. S.V. Ivanova, Tsennosti i Smysly, 5, 4 (2012).

2. S.V. Ivanova $O$ spetsifike prinyatiya reshenii $v$ otechestvennoi sisteme obrazovaniya s uchetom vneshnikh uslovii v 80-90 gg. XX v. - 2000-e gg. $X X I$ v. (Moskva, 2013) [In Rus]

3. M.V. Boguslavskii, Problemy sovremennogo obrazovaniya-Elektronnyi zhurnal, 6, 99 (2012).Available online: URL http://www.pmedu.ru. (accessed on 14.12.2015) [In Rus]

4. M.A. Lukatskii, Opisatel'naya, ob"yasnitel'naya $i$ predskazatel'naya funktsii sovremennoi pedagogicheskoi nauki (Moskva, 2014) [In Rus]
5. Federal'nyi zakon Rossiiskoi Federatsii «O gosudarstvennomyazykeRossiiskoiFederatsii». Prinyat 01.06.2005g. [Elektronnyi resurs]. Available online:

URL http://www.consultant.ru/document/cons_doc_LAW _162634(accessed on 22.06. 2015) [In Rus]

6. Zakon RF "O yazykakhnarodovRossiiskoiFederatsii". Prinyat 25.10.1991 g. (red. ot 12.03.2014). Available online:

URL http://www.consultant.ru/document/cons_doc_LAW _ 160106. (accessed on 24.09.2015) [In Rus]

7. Zakon SSSR «O yazykakhnarodov SSSR». Prinyat 24.04.1990g. Available online: URL http://russia.bestpravo.ru/ussr/data01/tex10935.htm. (accessed on 02.08.2015) [In Rus]

8. Konstitutsiya Respubliki Armeniya (s izmeneniyami). Prinyata 05.07.1995g. Available online: URL http://www.parliament.am/legislation.php?sel=show $\& \mathrm{ID}=1 \&$ lang=rus. (accessed on 12.10.2015) [In Rus]

9. Zakon Respubliki Armeniya «O yazyke». Prinyat 17.04.1993 g. Available online: URL http://www.parliament.am/legislation.php?sel=show $\& \mathrm{ID}=1793 \&$ lang=rus. (accessed on 17.12.2015) [In Rus]

10. Russkii yazyk kak inostrannyi nachnut sdavat's etogo goda pri postuplenii v vuzy Armenii.

11. Available online: URL http://newsarmenia.ru/society/20120229/42621211.h tml(accessed on 10.11.2015) [In Rus]

12. A.Ya. Khachikyan, VestnikMAPRYaL, 52, 20 (2006)

13. S. Zolyan, Russkii yazyk zarubezh'ya, (Zlatoust, Sankt-Peterburg, 2013)

14. A. Gazazyan, Deutsche Welle. 25.07.2012. Available online: URL http://www.dw.de/armeniyane-khochet-zabyvat'-russkii-yazyk/a-16121693 (2012) (accessed on 19.02.2016)

15. Russkii yazyk $v$ mire, (Olma-Press, Moskva, 2003) [In Rus]

16. L.A. Verbitskaya, Pedagogicheskii zhurnal Bashkortostana, 6, 13, (2013)[In Rus] 